\title{
EFFECTS OF CREATIVE ACCOUNTING ON THE FUTURE OF THE COMPANY
}

\section{Veronika Fišerová}

\section{Key words:}

Creative accounting, IFRS, tax, balance-sheet, statement income, financial reporting

\section{Klíčová slova:}

Kreativní účetnictví, IFRS, daň, rozvaha, výkaz zisku a ztrát

\begin{abstract}
This article is about creative accounting in join stock company, it shows advantages and disadvantages and it also describes reasons why the share holders deform financial statements. On the simple example it will shown the impact of creative accounting and its declarations. Under the term "creative accounting" is hidden preventing accounting and auditorial reports about the real state of company and consequently providing if incorrect information. The goal of this article is to show how the practising creative accounting can influence the declaration of operating results in the company.
\end{abstract}

\begin{abstract}
Abstrakt
Článek se zabývá .kreativním účetnictvím v akciové společnosti, ukazuje výhody a nevýhody a také popisuje důvody akcionářů deformovat účetní výkazy
\end{abstract}

\section{Introduction}

Sentence read at the beginning of almost every business book is that accounting adjustments as follows from the editing of accounting system after $1^{\text {st }}$ January 1993 is "to show the economic reality faithfully". This is a general fact to describe the function of accounting. Theory on one hand and practice on the other but we will try not to confront theory with practice. The problem which arises in the moment when the company is lead by people who focus on short-term and short-sighted profit taking is the little word "faithfully". When these people perceive the accounting as a necessary evil and a tool with which they could play and if they find the accounts whose out of fear of dismissal or ignorance are able to account anything that their boss "invent" the problem arises and may have consequences for the infinite future of the whole company.

This approach creates a new "kind of" accounting which is called in accounting practices, creative. It is creative mainly because their primary mission does not follow accountants or tax laws but mostly a "clever" idea of the owners or in other words "creative attitude" where the imagination plays a decisive role. ${ }^{1}$

In the following paragraphs of article we will discuss the reasons, advantages, disadvantages and effects of creative accounting ways and how to prevent such accounts practices and perhaps even better how to avoid it and example

\footnotetext{
${ }^{1}$ KOVANICOVÁ, D. a kol. Finanční účetnictví - světový koncept. Polygon, 2005. 526 s. ISBN 80-7273-129-7. str. 58.
} 


\section{Characteristics of the creative accounting concept}

Although today there is enough material on this issue, in accounting practices this phenomenon appears very often and it surprises me how far are some owners able and willing to go due vision of money ${ }^{2}$.

If there were the perfect environment, the perfectly unblemished people or even better no "creative" entrepreneurs, there might operate only two types of accounting - management and financial one. Management accounting at its core deals with the cost structure dividing cost in terms of species and or purpose, calculations, the activities of individual departments and thus can generalize its internal usage based on internal accounting.

In contrast financial accounting represents the company externally, provides the information to external stakeholders. In describing the basic elements of accounting is clear that somewhere in between creative accounting just being born. Accounting is a language and could be easily read by those who understands it. The necessary economic information could be easily found but also when the rules are used "the right way" they could be unprecedented.

Creativity in the accounting therefore comes at a time when the true background, figures and results should reach the public. This transforms the actual financial statements to those which the owners would like to achieve as positive and favourable results of the company. At this moment there start internal processes in which the owners choose the way they will follow. For such a decision the experts on accounting and tax issues (auditors or tax advisors) are usually present. ${ }^{3}$ Even though they have thousands of compelling arguments why not to use creativity in accounting in the most cases do nothing else than to retreat from their view although is supported by arguments based on the accuracy of the law. It is the shareholders and directors who are responsible for the accuracy of accounts. The paradox however remains the fact that the experts must to find out the accounting and tax levers to fix situation when the enterprise gets into trouble trough its creativity.

\section{The reasons of creative accounting}

The reasons for creative accounting could be several. To defend the owners of companies the creativity by itself can sometimes come from the very person who maintains the accounts and this is time to question whether that creativity is deliberate or caused by lack of financial knowledge. At this point necessary steps have to be taken by the owners.

Such a questions, however, does not have to be ask when the owners of creative accounting are also the owners of enterprise. There is always a conscious thing. Most of the owners are warned in advance of the possible dangers and risks that result from their decisions. ${ }^{4}$

Another element that comes into contact with the financial statements is management. If it is a large company managers are usually valuated according to company earnings. We should imagine enterprise which owners are also part of management and therefore there is no separation and all decisions do not go through the management, but directly from shareholders. Then we can analyze the reasons for creative accounting. In its essence there is

\footnotetext{
${ }^{2}$ ITTELSON, T. Financial Statements: A Step-by-Step Guide to Understanding and Creating Financial Reports. Publisher: Career Pr.Inc. 2009. 285 p. ISBN 978-160163-023-0. p. 146

${ }^{3}$ TRACY, J. How to Read A Financial Report. Publisher: Wiley. 2009. 216 p.ISBN 978-047-132-706-6. p. 26

${ }^{4}$ CARL, S., REEVE, J., DUCHAC, J. Financial Accounting. Publisher: South-Western College Pub. 2008. 920

p.ISBN 978-032-466-378-5. p. 387
} 
always "only" two reasons; the overestimation or underestimation of the individual components of financial statements and it corresponds accordingly to what is needed to get. If the company (not the new established company) needs to gain a greater amount of the loan, it is clear that they must have their assets in the desired positive values. In the specific example below shows what all such an artificial overestimation can cause. The same procedure should be used by even a moment the company needs to attract investors. Converse steps will be proceeding with applying for grants or tax optimization of course.

Whatever the reason is the creative accounting will always be reflected in financial indicators and ultimately the of company solvency, because not everything that looks like profit is really a profit. The truth is that even at the moment of artificial overestimation of financial ratios the company could fall into insolvency, bankruptcy, insolvency, etc. That is the essence of the creative accounting that eventually affects everything and the situation grow to the stage where is difficult to save anything.

\section{Advantages and disadvantages}

Although the present text refers rather to the disadvantage of creative accounting and identifies with not to use it, I'd like to add also the knowledge from my accounting practices that there are not always so catastrophic scenarios. There are situations where creative accounting and its impact are not let to go too far and are used in the short term and rather make the "gear" stone than some kind of permanent condition.

Yes, there are also company owners who fully recognize the risks and impacts of fictional accounts, so they use creativity sparingly and then rearranged the facts so that their financial statements comply with its primary mission and the faithfully reflects the economic reality of company at the end. ${ }^{5}$

\section{How to avoid creative accounting}

Large restriction on creative accounting could be seen at so-called harmonization of financial reporting and by application of mandatory IFRS (International Financial Reporting Standards) IAS, which are international guidelines for accounting and also preparation and presentation of financial statements published by the International Accounting Standards Board (IASB International Accounting Standards Board).

\footnotetext{
${ }^{5}$ MULFORD, Ch., COMISKEY, E. The Financial Numbers Game: Detecting Creative Accounting Practices. Publisher: Wiley. 2005. 408 p. ISBN 978-047-177-073-2. p. 47
} 
Chart 1: Requirements for financial statements

\begin{tabular}{|l|l|l|l|}
\hline Country & Balance Sheet & $\begin{array}{l}\text { Statement of Profit } \\
\text { and Loss }\end{array}$ & $\begin{array}{l}\text { Statement of Equity } \\
\text { Changes }\end{array}$ \\
\hline Great Britain & required & required & $\begin{array}{l}\text { required just from } \\
\text { large companies }\end{array}$ \\
\hline France & required & required & not required \\
\hline Germany & required & required & not required \\
\hline Canada & required & required & required \\
\hline Japan & required & required & required for VOS \\
\hline
\end{tabular}

Source: Iqbal Melcher, Elmallah: Intenational Accounting - A Global Perspective, South - Western College Publishing, 1997. 121 p., p.98

IFRS would have "forced" most of the companies follow practices that are authentic and comparable. The changes would apply to understanding the concepts of assets, liabilities, costs, revenues, capital, etc.

\section{The possible concrete effects of creative accounting to company XY}

We have the XY Company, which bought the company to bankruptcy and decided to continue in the same activities. The new shareholders have decided to ask the bank for a loan/credit, because they want to expand and modernize production range. The bank offered a loan/credit for that but the company had to submit the appropriate documents, balance sheet, and profit and loss for the previous period and current period.

Shareholders found out that the requirements of the bank could not be met and have decided to take only artificially increase the equity accounting and also an inventory item to the balance sheet assets equal liabilities. XY Company has received the loan, based on the evidence presented to the bank (we will not address how money from the credit used was).

Hereby the company is committed to the bank to comply with the terms of the contract. It was the year end and it was necessary to create financial statements and tax returns. Even before the artificially inflated value of the stock and capital funds account, the company reported a loss. For purposes of the bank was necessary to recognize so-called "black" numbers. Creative accounting had to be used again and inventory items needed to be adjusted also. Here, thanks to the overstatement of assets was created a large tax obligation, which the company had to pay. The end of year was closed with a positive economic profit. The following year there was again a partial change in ownership. There was also a change in leadership and philosophy. The company began to fulfil its commitments to both suppliers and the government and state institutions and the company's debt actually grew. Banking institute is under the conditions of the contract, states must submit claims with a certain level as well as the status of binding commitments, which keeps the company in an ever "wanted" of insolvency, as well as other conditions of the loan company is able to stand up for their condition and any necessary statement goes for some creative accounting. Today the situation is just before the company bankruptcy working on her recovery, competitiveness and capital inflows. 
Chart 2: Comparison fact/fiction balance sheet

\begin{tabular}{|l|l|l|l|l|l|}
\hline Prefix. & ASSETS & \multirow{2}{*}{ No. } & 2009 reality & 2009 fiction & difference \\
\hline & Assets in sum & 001 & 8454 & 11454 & -3000 \\
\hline B. & Long term assets & 003 & 2000 & 2000 & 0 \\
\hline C. & Short term assets & 031 & 6454 & 9454 & -3000 \\
\hline C.I. & Inventor & 032 & 500 & 3500 & -3000 \\
\hline C.II. & Long term outstanding & 039 & 650 & 650 & 0 \\
\hline C.III. & Short term outstanding & 047 & 5201 & 5201 & 0 \\
\hline C.IV. & Short term financial assets & 057 & 103 & 103 & 0 \\
\hline
\end{tabular}

\begin{tabular}{|l|l|l|l|l|l|}
\hline Prefix. & Debts & No. & $\begin{array}{l}2009 \\
\text { reality }\end{array}$ & $\begin{array}{l}2009 \\
\text { fiction }\end{array}$ & difference \\
\hline & Debts in sum & 066 & 8454 & 11454 & -3000 \\
\hline A. & Owned capital & 067 & -1534 & 1466 & -3000 \\
\hline A.I. & Joint stocks & 068 & 2000 & 2000 & 0 \\
\hline A.II. & Capital funds & 072 & 300 & 1300 & -1000 \\
\hline A.III. & Reserve fund & 077 & 400 & 400 & 0 \\
\hline A.IV. & Trading income (last years) & 080 & -3251 & -3251 & 0 \\
\hline A.V. & Trading income (current period) (+/-) & 083 & -983 & 1017 & -2000 \\
\hline F & Foreign sources & 084 & 9925 & 9925 & 0 \\
\hline B.I. & Reserve & 085 & 0 & 0 & 0 \\
\hline B.II. & Long term obligations & 090 & 620 & 620 & 0 \\
\hline B.III. & Short term obligations & 101 & 6305 & 6305 & 0 \\
\hline B.IV. & Bank loan & 113 & 3000 & 3000 & 0 \\
\hline C. & Other debts & 117 & 63 & 63 & 0 \\
\hline C.I. & Accruing & 118 & 63 & 63 & 0 \\
\hline Source: & (n) Bance shet XY company & & & \\
\hline
\end{tabular}

Source: Inner Balance sheet XY company

\section{Chart 3: Asset allocation}

\begin{tabular}{|c|c|c|}
\hline \multicolumn{3}{|c|}{ Asset allocation } \\
\hline \multirow[b]{2}{*}{2009 Fiction } & Long term assets & Short term \\
\hline & 2000 & 9454 \\
\hline 2009 Reality & 2000 & \\
\hline
\end{tabular}

Source: Own calculation 


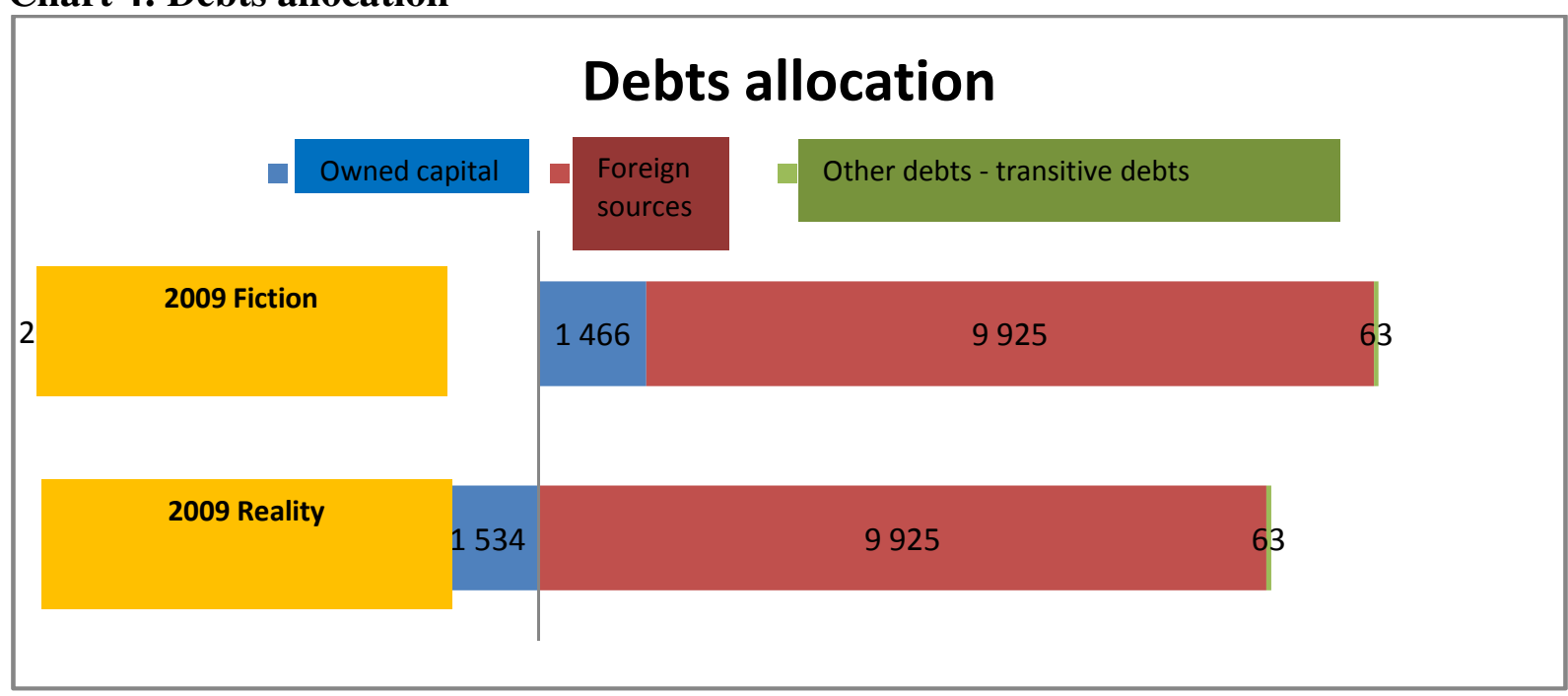

Source: Own calculation

\section{Conclusion}

I believe that the introduction of international accounting standards will help to prevent the formation of creative accounting and thus forming a fully functioning system of comparable financial statements, an also increase the trust in enterprises, improving the ability to raise funds and mutual competitors comparability. Furthermore, I believe that honesty and ethical behaviour in business is largely dependent on fiscal policy of each country. If the government does not create adequate environment for entrepreneurship, the level of taxation ever moves upwards or companies' inaccessibility of loans increases, more activity in creative accounting could be always expected. Of course, the ideal situation for banks and financial authorities is to reach the complete truth about the situation of the company and all of its transactions. It is, however, a pity if our country's fiscal policy which directs not against business but vice versa. At this point the entrepreneurs would also cease to go abroad and stay its residence in the home country.

However, creativity in the accounting and falsifying financial statements is the primary responsibility which always lies on shoulders of company owners or management.

\section{Literature:}

[1] CARL, S., REEVE, J., DUCHAC, J. Financial Accounting. Publisher: South-Western College Pub. 2008. ISBN 978-032-466-378-5. 920 p.

[2] ITTELSON, T. Financial Statements: A Step-by-Step Guide to Understanding and Creating Financial Reports. Publisher: Career Pr.Inc. 2009. ISBN 978-160163-023-0. $285 \mathrm{p}$.

[3] KOVANICOVÁ, D. a kol. Finanční účetnictví - světový koncept. Polygon, 2005. ISBN 80-7273-129-7. $526 \mathrm{~s}$.

[4] MELCHER, I.: International accounting - A global perspective. Publisher: South Western College. 1997. 121 p.

[5] MOST, K. The Future of the Accounting Profession: A Global Perspective. Publisher: Quorum Books. 1993. ISBN 978-089-930-726-8. 240 p. 
[6] MULFORD, Ch., COMISKEY, E. The Financial Numbers Game: Detecting Creative Accounting Practices. Publisher: Wiley. 2005. ISBN 978-047-177-073-2. 408 p.

[7] MULFORD, Ch., COMISKEY, E. Creative cash flow reporting. Publisher: Wiley. 2005. ISBN 978-047-146-918-6. 432 p.

[8] SCHOLLEOVÁ, H. Ekonomické a finanční řízení pro neekonomy. Praha: Grada Publishing. 2008. ISBN: 978-80-247-2424-9.256 s.

[9] TRACY, J. How to Read A Financial Report. Publisher: Wiley. 2009. ISBN 978-047132-706-6. $216 \mathrm{p}$.

[10] ZAFAR, M., AMIN, A. International accounting: A global perspective. Publisher: South-Western Pub. 1997. ISBN 978-053-883-739-2. 610 p.

[11] ZMEŠKAL, Z., DLUHOŠOVÁ, D. Company financial performance prediction at risk by simulation metodology. Ostrava: VŠB - Technická univerzita. 2008. ISBN: 978-80248-1846-7. $11 \mathrm{p}$.

\section{Legislative acts}

České účetní standardy

Vyhláška č. 500/2002 Sb., kterou se provádějí některá ustanovení zákona č. 563/1991

Sb., o účetnictví, ve znění pozdějších předpisů

Zákon č. 563/1991 Sb., o účetnictví, ve znění pozdějších předpisů

Zákon č. 586/1992 Sb., o daních z př́ijmů, ve znění pozdějších předpisů

\section{List of charts:}

Chart 1: Requirements for financial statements

Chart 2: Comparison fact/fiction balance sheet

Chart 3: Asset allocation

Chart 4: Debts allocation

\section{JEL classification: M41}

\section{Ing. Veronika Fišerová}

Interní doktorand katedry účetnictví

Slezská univerzita v Opavě

Obchodně podnikatelská fakulta v Karviné

Univerzitní náměstí 1934/3

73340 Karviná

verfis@centrum.cz 